\title{
Acute-lethal toxicity test on juvenile Oreochromis niloticus exposed to Piper betle extract under static exposure
}

Acute-lethal toxicity test
Siti Nurafiqah Mustapha

Department of Marine Science, Kulliyyah of Science, International Islamic University Malaysia, Kuantan, Malaysia

Akbar John

Institute of Oceanography and Maritime Studies (INOCEM), Kulliyyah of Science, International Islamic University Malaysia, Kuantan, Malaysia

Hassan Sheikh

Department of Fisheries and Aquaculture Sciences, Universiti Malaysia Terengganu, Kuala Terengganu, Malaysia

Ahmad Jalal Khan Chowdhury

Department of Marine Science, Kulliyyah of Science, International Islamic University Malaysia, Kuantan, Malaysia, and

Kamaruzzaman Yunus

International Islamic University Malaysia, Kuala Lumpur, Malaysia

\begin{abstract}
Purpose - This study aims to evaluate the effect of Piper betle leaf extract towards the acute-lethal toxicity, LC50 of red Nile tilapia juveniles (Oreochromis niloticus).

Design/methodology/approach - Ten red Nile tilapia juveniles per tank (in triplicate) were used as an experimental fish for the LC50 bioassay. Five different concentrations of $P$. betle extract; $80 \mathrm{ppm}, 90 \mathrm{ppm}$, $100 \mathrm{ppm}, 110 \mathrm{ppm}$ and $120 \mathrm{ppm}$, were tested on the red Nile tilapia juveniles and one tank was acting as a control. The progress of the LC50 and lethal time of fish mortality were observed and recorded within the random interval of $96 \mathrm{~h}$. The value for LC50 was determined as $100 \mathrm{ppm}$ of $P$. betle leaf extract. Higher number of fish mortalities was observed when concentration higher than $100 \mathrm{ppm}$ was tested on to the red Nile tilapia juveniles.
\end{abstract}

Findings - Data obtained shows that the $P$. betle concentration of $120 \mathrm{ppm}$ accelerated the fish mortality period.

(C) Siti Nurafiqah Mustapha, Akbar John, Hassan Sheikh, Ahmad Jalal Khan Chowdhury and Kamaruzzaman Yunus. Published in Ecofeminism and Climate Change. Published by Emerald Publishing Limited. This article is published under the Creative Commons Attribution (CC BY 4.0) licence. Anyone may reproduce, distribute, translate and create derivative works of this article (for both commercial and non-commercial purposes), subject to full attribution to the original publication and authors. The full terms of this licence may be seen at http://creativecommons.org/licences/by/4.0/ legalcode

This work was supported by the Research Initiative Grant Scheme for Post-Doctoral Fellow (RPDF 18-004-0004), 2018 and Fundamental Research Grant Scheme (FRGS 19-0210-0629).
Received 20 December 2019 Revised 11 March 2020 Accepted 15 March 2020 
EFCC 1,2

Originality/value - However, adaption of $P$. betle extract occurred after $50 \mathrm{~h}$, as there was no fish mortality observed within the time.

Keywords Piscicide, LC50, Oreochromis niloticus, Piper betle, Leaf extract

Paper type Research paper

\section{Introduction}

Aquaculture industries are on the rise as the supply of wild fishes is becoming limited because of the pollution that occurs in their surrounding environment (FAO, 2014). Fishes are one of the main sources of protein and are essential for human health. Hence, it is crucial to provide a sustainable fish production via artificial means such as aquaculture. A sustainable aquaculture can play a significant role in achieving a more environmentally and economically viable fish production (Cressey, 2009). However, diseases and fish mortalities are virtually inevitable when it comes to large-scale culture and intensive fish farming. These circumstances are triggered by the artificial and stressful aquaculture environment, which is different from the natural habitat. It is vital that the environment in which fishes are cultured is similar to the fish's natural habitat, which can guarantee better fish health and enhance fish growth (USEPA, 2000).

Piscicide could be solutions to mitigate the challenges faced by aquaculture industries. Synthetic piscicide is usually used to inhibit the growth of fungi, bacteria or the breeding of non-target fishes. However, synthetic piscicide is chemically designed, non-biodegradable, harms the water-bodies and indirectly pollutes the marine ecosystem (Adesina, 2008; Adeyemo, 2012). Therefore, piscicide of plant origin has become an alternative and is used in aquaculture industries. Piscicide of plant origin is natural, organic and does not affect the targeted fish. It is also ecologically safe to the environment and to the consumers. Mainly, the eco-toxic properties are the main reason fish farmers are interested in natural piscicide (Singh and Singh, 2002; Son and Mohiseni, 2017).

Plant-based natural products are low-cost and pose lower risk of toxicity, hence, herbs and medicinal plants could be source of alternative antimicrobial agents, especially piscicide, to be used in fish farming and aquaculture (Madhuri et al., 2012). The therapeutic properties of these plants can be attributed to presence of various active compounds such as essential oils, flavonoids, alkaloids, pigments, phenolic, steroids and terpenoids (Citarasu, 2010). Natural products are also easily available, biodegradable, safe to consume, produce minimal environmental hazards and less adverse effects (Singh and Singh, 2002).

In this study, Piper betle was evaluated for its efficiency as a plant-origin piscicide. P. betle is known for the medicinal properties and has been used for years in fish farming industries. It was reported that betel leaf contains phytochemical constituents with biological properties such as anticancer, antioxidant, antibacterial, antifungal, insecticidal, cytotoxic, wound-healing activity and others (Al-Adhroey et al., 2010; Gopumadhavan et al., 2005; Nalina and Rahim, 2007; Widowati et al., 2013; Wirotesangthong et al., 2008), Therefore, the usage of $P$. betle has to be explored for its potential to boost the growth performance of farmed fish.

Biotic factors and environmental stress can be measured via biological indicators to determine the level of pollution of an area. In particular, long-living organisms such as fishes are sensitive to the impact of a complex mixture of chemicals in a specific aquatic ecosystem, integrating the environmental load over time and space. The existence or absence of fish can be used to measure the level of pollution in that area. Few species from freshwater and seawater, typically algae, invertebrate and fishes, are usually used as bioindicator in toxicity tests (Syngai et al., 2016). Tilapia is one of the largest species that is being cultured by fish farmers. This is because of the robustness of tilapia and its lower feeding frequency compared to other fish species (Gjedrem and Baranski, 2009). While some 
of the tilapia hybrids have gained widespread popularity because of their ability to grow in brackish and seawater system (Fitzsimmons, 2016; Lim and Webster, 2006).

Red Nile tilapia is mainly freshwater fish species and belongs to the family Cichlidae, the third largest family of bony fish. Tilapia is known as a low-cost protein source and other nutrients such as vitamins, minerals and essential fatty acids that are needed to maintain health. They have been cultured widely in a different culture system and become well accepted by people. Tilapia is becoming a very important commercial venture in Malaysia as it is a popular breed in aquaculture, with short generation time and has rapid weight gain (Ogunbona and Ijimakinde, 2014; Taweel et al., 2013). Therefore, therapeutic effect of $P$. betle on red Nile tilapia (Oreochromis niloticus) was investigated. Studies on the acute toxicity of $P$. betle extract on tilapia juveniles are still scanty. Determining the toxicity of $P$. betle leaves extract on tilapia is important to determine the active and lethal concentrations of the extract.

\section{Materials and methods}

\subsection{Materials}

Fresh and mature leaves of $P$. betle were purchased from the local market in Kuantan, Pahang, Malaysia. Tilapia juveniles were purchased from a fish farm at Kuala Selangor, Pahang; namely, SAG AQUA Group and the juveniles were then sent to Institute of Oceanography and Maritime Studies (INOCEM) IIUM for acclimatization period.

\subsection{Preparation of P. betle extract}

Approximately, $1 \mathrm{~kg}$ of mature and fresh leaves of $P$. betle were rinsed with flowing water to remove any adhering foreign matters and soil materials. Then, the leaves were oven-dried at $45^{\circ} \mathrm{C}$ for 36 to $48 \mathrm{~h}$ until a constant weight was achieved. The leaves were then pulverized into powdered form by using an electronic grinder and sieved $(63 \mu \mathrm{m})$ to obtain smaller size powder particles. Lastly, the processed powder was stored in an airtight bottle and kept at $4^{\circ} \mathrm{C}$. The concentrated stock solution of $P$. betle leaves was prepared based on the method by Tasneem et al. (2014).

\subsection{Preparation of red Nile tilapia (Oreochromis niloticus) culture}

Tilapia juveniles were acclimated in the tanks for a minimum of 12-14 days before the toxicity test was carried out. The tanks were supplied with continuous aeration and filled with dechlorinated water under natural photoperiod cycle ( $12 \mathrm{~h}$ light: $12 \mathrm{~h}$ dark). During the acclimation period, all juveniles were fed with supplementary feed twice a day (Adesina et al., 2013; Ayoola et al., 2011). All the red Nile tilapia juveniles were starved for $24 \mathrm{~h}$, a day before the treatment and throughout the experiment. This is to prevent any crosscontamination from the faeces of the tilapia.

\subsection{Acute-lethal toxicity test $\left(L_{50}\right)$}

The experimental procedures for the acute toxicity test were to determine the $96 \mathrm{~h} \mathrm{LC}_{50}$ of the $P$. betle towards red Nile tilapia juveniles. Bath immersion treatment method with some modifications based on literatures was applied in this study (Audu et al., 2015; Thophon et al., 2003; Zhao et al., 2014). A static bioassay system was practiced in the study. Water was not changed in experimental tanks throughout the test. The experiment consisted of five concentration gradients; $80 \mathrm{ppm}, 90 \mathrm{ppm}, 100 \mathrm{ppm}, 110 \mathrm{ppm}$ and $120 \mathrm{ppm}$ of $P$. betle leaf extract and one control with continuous aeration. Each 5L tank contained 10 juvenile red Nile tilapias. Experimental tanks were prepared in triplicates. The test was carried out under an ambient temperature of $27 \pm 3^{\circ} \mathrm{C}$. The water quality (water temperature, dissolved 
EFCC

1,2

82

oxygen $[\mathrm{DO}]$ and $\mathrm{pH}$ ) was monitored and recorded prior to the test and at the end of the test. The number of fish mortality was calculated and the behaviour was observed and recorded at random intervals until $96 \mathrm{~h}$.

\section{Results}

The red Nile tilapia, which has been treated with different concentrations of $P$. betle leaf extract was compared to the control tank (Table 1). The result showed that the excessive exposure to the $P$. betle leaf extract led to mortality. The acute-lethal toxicity $\left(\mathrm{LC}_{50}\right)$ of Oreochromis niloticus showed that $100 \mathrm{ppm}$ is the lethal concentration of $P$. betle leaf extract (Figure 1). Table 1 shows that $100 \mathrm{ppm}$ resulted in $50 \%$ mortality,

\begin{tabular}{lcccrrr}
\hline & \multicolumn{7}{c}{$\begin{array}{c}\text { Test concentration } \\
(\mathrm{ppm})\end{array}$} \\
$\begin{array}{l}\text { Time } \\
\text { h) }\end{array}$ & Control & 80 & 90 & 100 & 110 & 120 \\
\hline 0 & 0 & 0 & 0 & 0 & 0 & 0 \\
1 & 0 & 0 & 0 & 0 & 0 & 1 \\
2 & 0 & 0 & 1 & 1 & 1 & 1 \\
4 & 0 & 0 & 0 & 1 & 1 & 1 \\
8 & 0 & 1 & 0 & 0 & 0 & 0 \\
12 & 0 & 1 & 1 & 1 & 1 & 2 \\
16 & 0 & 1 & 0 & 0 & 1 & 1 \\
24 & 0 & 0 & 1 & 1 & 1 & 2 \\
36 & 0 & 1 & 0 & 0 & 1 & 0 \\
48 & 0 & 0 & 1 & 1 & 0 & 0 \\
50 & 0 & 0 & 0 & 0 & 0 & 0 \\
62 & 0 & 0 & 0 & 0 & 0 & 0 \\
72 & 0 & 0 & 0 & 0 & 0 & 0 \\
96 & 0 & 0 & 0 & 0 & 0 & 0 \\
Total number of death & 0 & 4 & 4 & 5 & 6 & 8 \\
Total percentage of fish mortality (\%) & 0 & 40 & 40 & 50 & 60 & 80 \\
\hline
\end{tabular}

Figure 1.

Median lethal concentration LC50 value of fish mortality (\%) against the concentration of P. betle leaf extract (ppm)

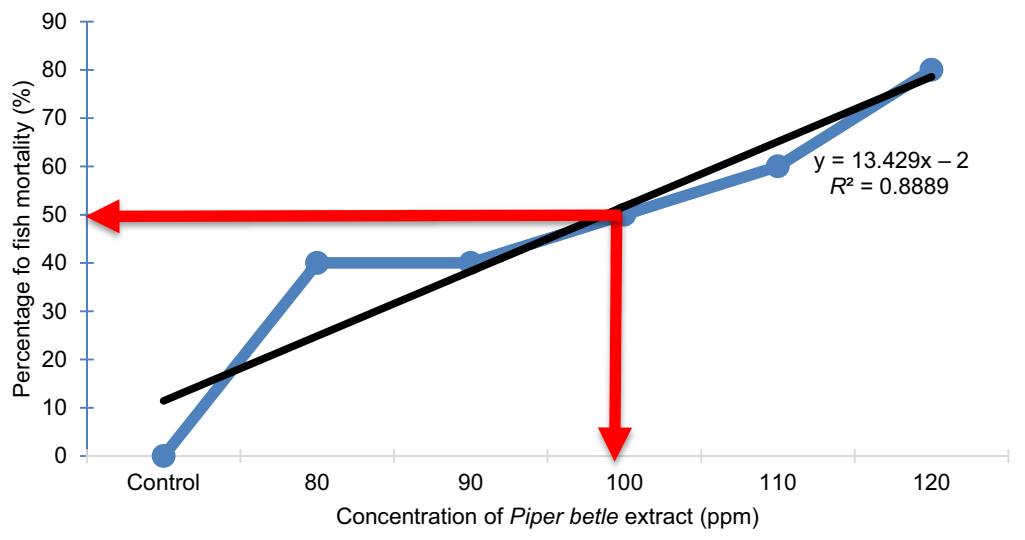

Percentage of fish mortality (\%) Linear (Percentage of fish mortality (\%)) 
whereas higher concentration of the leaf extract triggered higher percentage of mortality. The correlation coefficient $(R)$ value between concentration of the leaf extract and the percentage of fish mortality was 0.8889 .

However, the juveniles started to show resistance after $50 \mathrm{~h}$ of treatment where no mortalities were observed in all tanks until the end of the $96 \mathrm{~h}$ test. The number of dead red Nile tilapia juveniles at different concentration of $P$. betle extract was monitored and recorded for $96 \mathrm{~h}$ (Table 1). As shown in Table 1, $120 \mathrm{ppm}$ of $P$. betle leaf extract also showed the highest percentage of fish mortality with $80 \%$ death at the end of the test. This concentration also accelerates the death period, where first mortality occurred in the first hour. The concentration of $80 \mathrm{ppm}$ and $90 \mathrm{ppm}$, which were less than the median lethal concentration, resulted in $40 \%$ mortality. The death period for the first mortality was also longer in the $80 \mathrm{ppm}$ concentration, which was $8 \mathrm{~h}$. Only control tank showed zero mortality at the end of the experiment, which indicated that the red Nile tilapia juveniles were in healthy condition throughout the experiment. However, the number of the juveniles started to show a constant number in each $P$. betle treatment tanks after $50 \mathrm{~h}$ of treatment.

Fish mortality may be affected by other factors, such as the changes in water parameters (Ayoola, 2008; Olufayo, 2009). In the current study, water parameters for this study were recorded prior and after the toxicity test (Table 2). The temperature and DO between each tested tank did not change significantly. The temperature varied from $27.15^{\circ} \mathrm{C}$ to $28.32^{\circ} \mathrm{C}$, whereas the DO ranged between $5.55 \mathrm{mg} / \mathrm{L}$ and $5.85 \mathrm{mg} / \mathrm{L}$. In contrast, $\mathrm{pH}$ values recorded slight difference before and after the experiment, especially in the $120 \mathrm{ppm}$ treatment tanks. It is possible that the cause of fish mortality was associated with the decrease in $\mathrm{pH}$ values.

The median lethal concentration that was obtained ( $100 \mathrm{ppm})$ from the study was less than the concentration that was reported by other plant extracts tested on the same species of tilapia fingerlings (Oreochromis niloticus). The median lethal concentration of Moringa oleifera seed powder was $242 \mathrm{ppm}$ and the aqueous extract of Euphorbia poisonii leaves was $7,130 \mathrm{ppm}$ which is more toxic. Other plant extract tested such as the aqueous extract of Ipomoea aquatic, Lepidagathis alopecuroides, Carica papaya and Nerium oleander showed that the mean lethal concentration to tilapia was 2,659 ppm, $880 \mathrm{ppm}, 700 \mathrm{ppm}$ and $400 \mathrm{ppm}$, respectively (Ayoola, 2011; Ayotunde et al., 2011).

\section{Discussions}

The behaviour of tilapia juvenile changed upon exposure to $P$. betle leaf extract and became either more aggressive or passive than the normal behaviour. These rapid behavioural changes were also reported by Fafioye (2012), where the fish exhibited these behaviours as well as mucus secretion on gills prior to death. These behaviours were shown to be dosedependent as they occurred less frequently at lower concentrations of the toxicant concentrations and increased at higher concentrations.

Tilapia juveniles showed different behavioural changes under different concentrations of $P$. betle extract. The juveniles expressed initial distress via swimming pattern, loss of balance and relentless gulping of air. Excessive mucus secretion and unusual lethargy were also observed. Few samples showed erratic swimming before settling at the bottom of the tank with slow opercular movement prior to death. However, these observations became less obvious with the increase of exposure time. Fish exposed to $120 \mathrm{ppm}$ displayed the most rapid behavioural changes.

Water quality parameters are indirectly affected by the compounds present in the $P$. betle leaf extract. These functional compounds were previously found to reduce the presence of oxygen in the water, which is vital for fish respiration (Maina, 2002). Herbal plants, especially $P$. betle leaf are known to have abundance of various active compounds such as 
EFCC

1,2

\section{4}

Table 2.

Water qualities of treatment tanks before and after experimental period

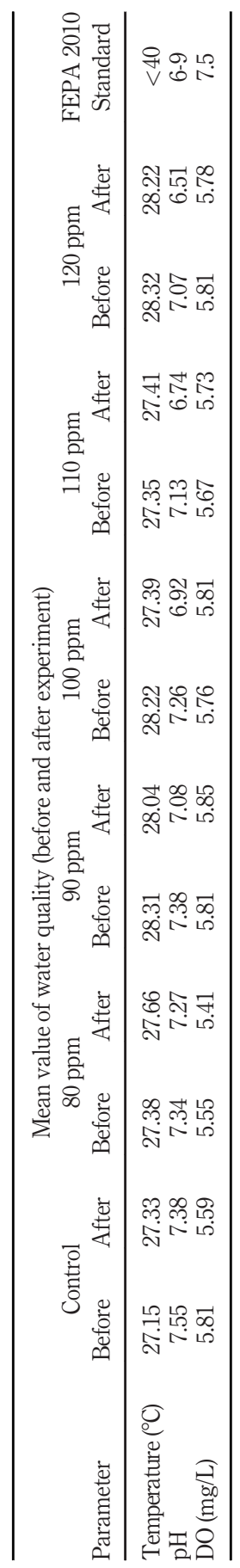


essential oils, flavonoids, alkaloids, pigments, phenolic, steroids and terpenoids (Citarasu, 2010). Hence, the presence of all these functional compounds is suspected to be the factor of the reducing DO, especially in higher concentration of $P$. betle leaf extract.

The $\mathrm{pH}$ value was inversely proportional to the increase in the concentration of the leaf extract. pH value could cause toxicity because of the imbalance of electrolyte (Milsom, 1993; Syngai et al., 2016). However, Aguinaga et al. (2014) exposed neotropical fish Hyphessobrycon eques to aqueous extract of Uncaria tomentosa bark and reported that the low level of DO is the main factor in fish mortality rather than changes of $\mathrm{pH}$. Yet, according to FEPA 2010 standard, the changes of water parameter in this study were within the acceptable standard. Hence, it is suggested that more research studies on the toxicity test of the $P$. betle extract in aquacultures should be investigated further for a detailed finding. The histology of toxic effect of the $P$. betle extract in the tilapia juveniles should also be given thorough attention.

\section{Conclusion}

In conclusion, the median lethal concentration of $P$. betle leaves towards tilapia juvenile within $96 \mathrm{~h}$ of exposure was $100 \mathrm{ppm}$. At lethal and sub-lethal doses of $P$. betle extract juveniles showed rapid changes of behaviour. Tilapia juveniles showed no more mortality after $50 \mathrm{~h}$ of exposure until the end of test at $96 \mathrm{~h}$.

\section{References}

Adesina, B.T. (2008), "Toxicity of Moringa oleifera (lam.) extract to Oreochromis niloticus fingerlings and juveniles", PhD Thesis, University of Ibadan, Nigeria.

Adesina, B.T., Omitoyin, B.O., Ajani, E.K. and Adesina, O.A. (2013), "Acute-lethal toxicity $\left(\mathrm{LC}_{50}\right)$ effect of Moringa oleifera (lam.) fresh root bark extract on Oreochromis niloticus juveniles under renewal toxicity exposure", International Journal of Applied Agricultural and Apicultural Research, Vol. 9 Nos 1/2, pp. 182-188.

Adeyemo, O. (2012), "Food safety and environmental health concerns: threats to sustainable aquaculture development in Nigeria”, World Aquaculture Conference 2012.

Aguinaga, Y.J., Claudiano, G.S., Marcusso, P.F., Ikefuti, C., Ortega, G.G. and Eto, S.F. (2014), "Acute toxicity and determination of the active constituents of aqueous extract of Uncaria tomentosa bark in Hyphessobrycon eques", Journal of Toxicology, Vol. 2014, pp. 1-5.

Al-Adhroey, A.H., Nor, Z.M., Al-Mekhlafi, H.M., Amran, A.A. and Mahmud, R. (2010), "Antimalarial activity of methanolic leaf extract of Piper betle L", Molecules, Vol. 16 No. 1, pp. 107-118.

Audu, B.S., Ajima, M.N. and Ofojekwu, P.C. (2015), "Enzymatic and biochemical changes in common carp, Cyprinus carpio (L.) fingerlings exposed to crude leaf extract of Cannabis sativa (L.)", Asian Pacific Journal of Tropical Disease, Vol. 5 No. 2, pp. 107-115.

Ayoola, S.O. (2008), "Toxicity of glyphosate herbicide on Nile tilapia (Oreochromis nilotus) juvenile", African Journal of Agriculture Research, Vol. 3 No. 12, pp. 825-834.

Ayoola, S.O. (2011), "Acute toxicity and histopathology of Nile tilapia (Oreochromis niloticus) fingerlings exposed to aqueous and ethanolic extracts of Euphorbia poissonii leaves", New Clues in Sciences, Vol. 1, pp. 55-68.

Ayoola, S.O., Kuton, M.P., Idowu, A.A. and Adelekun, A.B. (2011), "Acute toxicity of Nile tilapia (Orechromis niloticus) juveniles exposed to aqueous and ethanolic extracts of I. pomoea aquatic leaf", Nature and Science, Vol. 9 No. 3, pp. 91-99.

Ayotunde, E.O., Fagbenro, O.A. and Adebayo, O.T. (2011), "Toxicity of aqueous extract of Moringa oleifera seed powder to Nile tilapia Oreochromis niloticus (LINNE I779), fingerlings", International Research Journal of Agricultural Science and Soil Science, Vol. 1 No. 4, pp. 142-150.
Acute-lethal toxicity test 
EFCC

1,2

Citarasu, T. (2010), "Herbal biomedicines: a new opportunity for aquaculture industry", Aquaculture International, Vol. 18 No. 3, pp. 403-414.

Cressey, D. (2009), “Aquaculture: future fish”, Nature, Vol. 458 No. 7237, pp. 398-400.

Fafioye, O.O. (2012), "Acute and sub-acute toxicities of five plant extracts on white tilapia, Oreochromis niloticus (trewavas)”, International Research Journal of Agricultural Science and Soil Science, Vol. 2 No. 13, pp. 525-530.

Fitzsimmons, K.M. (2016), Global Tilapia Market Updates 2015, World Aquaculture Society 2016, Las Vegas.

Gjedrem, T. and Baranski, M. (2009), Selective Breeding in Aquaculture: An Introduction, 1st ed., London, Springer.

Gopumadhavan, S., Rafiq, M., Venkataranganna, M.V. and Mitra, S.K. (2005), "Antihistaminic and antianaphylactic activity of HK-07, a herbal formulation", Indian Journal of Pharmacology, Vol. 37 No. 5, pp. 300-304.

Lim, C. and Webster, C.D. (2006), Tilapia: Biology, Culture, and Nutrition, 1st ed., New York, NY, CRC Press.

Madhuri, S., Mandloi, A.K., Govind, P. and Sahni, Y.P. (2012), "Antimicrobial activity of some medicinal plants against fish pathogens", International Research Journal of Pharmacy, Vol. 3, pp. 28-30.

Maina, J.N. (2002), "Review structure, function and evolution of the gas exchangers: comparative perspectives", Journal of Anatomy, Vol. 201 No. 4, pp. 281-304.

Milsom, W.K. (1993), "Afferent inputs regulating ventilation in vertebrates”, in Bicudo J E. (Ed.), The Vertebrate Gas Transport Cascade, Adaptations and Mode of Life, CRC Press Boca Raton, FLla: CRC Press, pp. 94-105.

Nalina, T. and Rahim, Z.H.A. (2007), "The crude aqueous extract of Piper betle L. and its antibacterial effect towards Streptococcus mutans", American Journal of Biochemistry and Biotechnology, Vol. 3 No. 1, pp. 10-15.

Ogunbona, A.A. and Ijimakinde, B. (2014), "Response of tilapia Niloticus fed on different feeds composition", Journal of Fisheries and Aquatic Science, Vol. 9 No. 5, pp. 330-337.

Olufayo, M.O. (2009), "Haematological characteristics of Clarias gariepinus (Burchell 1822) juveniles exposed to Derris elliptia root powder", African Journal of Food Agriculture, Nutrition and Development, Vol. 9 No. 3, pp. 920-932.

Singh, D. and Singh, A. (2002), "Piscicidal effect of some common plants of India commonly used in freshwater bodies against target animals", Chemosphere, Vol. 49 No. 1, pp. 45-49.

Son, C.R.I.M. and Mohiseni, M. (2017), "Medicinal herbs, strong source of antioxidant in aquaculture: a mini review", Modern Applications in Pharmacy and Pharmacology, Vol. 1 No. 1, pp. 1-5.

Syngai, G.G., Dey, S. and Bharali, R. (2016), "Evaluation of toxicity levels of the aqueous extract of Allium sativum and its effects on the behaviour of juvenile common carp (Cyprinus carpio, L 1758)", Asian Journal of Pharmaceutical and Clinical Research, Vol. 9 No. 3, pp. 417-421.

Tasneem, S., Kauser, S. and H and Yasmeen, R. (2014), "Toxicity of two biopesticidal plants aqueous leaf extracts to Oreochromis mossambicus-histopathology of gill, liver and intestine”, Journal of Biopesticides, Vol. 7 No. 2, pp. 124-131.

Taweel, A., Shuhaimi-Othman, M. and Ahmad, A.K. (2013), "Assessment of heavy metals in tilapia fish (Oreochromis niloticus) from the Langat river and engineering lake in Bangi, Malaysia and evaluation of the health risk from tilapia consumption", Ecotoxicology and Environmental Safety, Vol. 93, pp. 45-51.

Thophon, S., Kruatrachue, M., Upatham, E.S., Pokethitiyook, P., Sahaphong, S. and Jaritkhuan, S. (2003), "Histopathological alterations of white seabass, lates calcarifer, in acute and subchronic cadmium exposure", Environmental Pollution, Vol. 121 No. 3, pp. 307-320.

United State Environmental Protection Agency (2000), "Methods for measuring the acute toxicity of effluents to freshwater and marine organisms", Environmental Monitoring and Support 
Laboratory, 4th ed. Cincinati, OH: United State Environmental Protection Agency (USEPA). www.epa.gov/sites/production/files/2015-08/documents/acutefreshwater-and-marine-wet-manual_ 2002.pdf (accessed 3 October 2018).

Widowati, W., Wijaya, L., Wargasetia, T.L., Bachtiar, I., Yelliantty, Y. and Laksmitawati, D.R. (2013),

"Antioxidant, anticancer, and apoptosis-inducing effects of piper extracts in HeLa cells", Journal of Experimental and Integrative Medicine, Vol. 3 No. 3, pp. 225-230.

Wirotesangthong, M., Inagaki, N., Tanaka, H., Thanakijcharoenpath, W. and Nagai, H. (2008), "Inhibitory effects of Piper Betle on production of allergic mediators by bone marrow-derived mast cells and lung epithelial cells", International Immunopharmacology, Vol. 8 No. 3, pp. 453-457.

Zhao, X., Gao, Y. and Qi, M. (2014), “Toxicity of phthalate esters exposure to carp (Cyprinus carpio) and antioxidant responses by biomarker", Ecotoxicology, Vol. 23 No. 4, pp. 626-632.

\section{Further reading}

Food and Agriculture Organization of the United Nations (2014), Fisheries and Aquaculture Statistics, Food and Agriculture Organization of the United Nations (FAO), Rome, Italy.

\section{Corresponding author}

Kamaruzzaman Yunus can be contacted at:kama@iium.edu.my

Expression of Concern: The publisher of Ecofeminism and Climate Change is issuing an Expression of Concern for the following article S.N. Mustapha, A. John, H. Sheikh, A.J.K. Chowdhury and K. Yunus (2020), 'Acute-lethal toxicity test on juvenile Oreochromis niloticus exposed to Piper betle extract under static exposure' published in Ecofeminism and Climate Change, Vol. 1 Issue 2, pp. 79-87, to inform readers that concerns have been raised regarding the research standards of this paper. An investigation is ongoing. Further information will be provided by Ecofeminism and Climate Change as it becomes available.

For instructions on how to order reprints of this article, please visit our website: www.emeraldgrouppublishing.com/licensing/reprints.htm Or contact us for further details: permissions@emeraldinsight.com 